\title{
Fermentasi Ikan Kembung (Rastrelliger sp.) dalam Pembuatan Peda dengan Penambahan Bakteri Asam Laktat (BAL) yang Terkandung dalam Terasi Empang pada Berbagai Konsentrasi Garam
}

\author{
Oleh : \\ Yuniati Fajri, AA. Sukarso, dan Dewa Ayu Citra Rasmi \\ Program Studi Pendidikan Biologi \\ Fakultas Keguruan dan Ilmu Pendidikan \\ Universitas Mataram
}

\begin{abstract}
ABSTRAK
Peda merupakan produk fermentasi ikan melalui penambahan garam pada kadar tertentu. Fermentasi Peda terbentuk karena penguraian senyawa lemak dan protein kompleks yang terdapat dalam tubuh ikan menjadi senyawa yang lebih sederhana dengan bantuan enzim dari mikroba fermentor. Berkaitan dengan hal tersebut telah dilakukan penelitian dengan tujuan mengetahui konsenterasi garam yang tepat dalam pembuatan peda yang ditambahkan BAL yang terkandung dalam terasi. Sampel ikan kembung yang diperoleh dari Pasar Bertais diambil sebanyak 36 ekor diberi perlakuan dengan 3 konsenterasi penggaraman yang berbeda $(15 \%, 20 \%$, dan $25 \%) \mathrm{b} / \mathrm{b}$ dan difermentasi melalui penggaraman I selama 7 hari dan penggaraman II selama 21 hari. Hasil fermentasi diamati untuk parameter warna, aroma, tekstur dan rasa peda. Data hasil penelitian diuji dengan uji hedonik oleh panelis ahli dan hasilnya dianalisis dengan uji Kruskal-Wallis. Hasil analisis data menunjukkan bahwa tidak ada perbedaan nyata antar perlakuan penggaraman dan penambahan BAL terhadap sifat hedonik Peda pada $p>0,05$. Namun, Peda yang paling diterima oleh panelis adalah Peda yang difermentasi dengan konsenterasi penggaraman $25 \%$.
\end{abstract}

Kata kunci: Fermentasi, Ikan Kembung ,Peda, Bakteri Asam Laktat (BAL), uji hedonik

\section{Fermentation of Mackerel (Rastrelliger sp.) in Making Peda Added with of Lactic Acid Bacteria (LAB) in Several Salt Concentrations}

\begin{abstract}
Peda is a fermentation products by additing of salt in certain concentrations. In the fermentation is occurred breaking the complex compound of fish's fat and protein into several simpler compounds by enzymes of fermentor agents (the microbes). This research was purposed to know exactly salt concentration in the process of making peda with addition of lactic acid bacteria from terasi. The type of this research is experiment. Population of this research is all Mackerels which are sold in Bertais market, and 36 of them are taken as sample, by purposive sampling. The treatment of this research consists of 3 concentration of salt, that is $15 \%, 20 \%$ and $25 \%$. Data was taken by using hedonic test by 5 expert panelists. Data was analyzed by using Kruskal-Wallis test. Result showed that there were no treatment differences of salt and lactic acid bacteria towards hedonic tests $(\mathrm{P}>0,05)$. Yet, the most acceptable of peda, is fermented within $25 \%$ salt concentration.
\end{abstract}

Key words :Fermentation, Mackerel fish, Peda, Lactic Acid Bacteria, Hedonic Test 
PENDAHULUAN

Deda merupakan salah satu produk fermentasi ikan oleh mikroorganisme melalui pengkondisian penambahan garam dengan kadar tertentu. Pembuatan peda merupakan teknik pengawetan ikan secara tradisional, mudah dilakukan dan tidak memerlukan peralatan khusus yang canggih. Proses fermentasi dalam pembuatan peda merupakan proses penguraian senyawa lemak dan protein kompleks yang terdapat dalam daging ikan menjadi senyawa yang lebih sederhana dengan bantuan enzim yang berasal dari tubuh ikan sendiri atau dari mikroorganisme (Khasanah, 2009).

Teknik fermentasi dalam pembuatan peda yang berkembang di masyarakat selama ini dilakukan dengan proses penggaraman sebanyak dua kali dengan menggunakan konsentrasi garam 25\% tanpa penambahan starter bakteri. Bakteri fermentor berasal tubuh ikan itu sendiri dan dari lingkungan tempat fermentasi dilakukan. Waktu fermentasi berlangsung selama $1-2$ minggu, sehingga cita rasa yang dihasilkan tidak terlalu tajam (Adawyah, 2006). Teknik fermentasi ini perlu dikembangkan lebih lanjut melalui penambahan starter bakteri fermentor. Bakteri fermentor dapat berupa bakteri yang ditambahkan dari sumber bakteri seperti dari terasi. Terasi merupakan produk fermentasi yang banyak mengandung BAL yang juga berperan dalam fermentasi peda. Santoso, dkk. (1999) menemukan bakteri-bakteri fermentor untuk Peda dan terasi berupa Lactobacillus cirvatus, L. sake, L. murinus, L. Plantarum, dan Streptococus termophilus.

Bakteri Asam laktat (BAL) merupakan jenis bakteri yang mampu menghasilkan asam laktat sebagai produk akhir dari proses metabolismenya. BAL memanfaatkan karbohidrat sebagai sumber nutrisi untuk proses metabolisme. Sumber karbohidrat yang digunakan berasal dari daging, susu, dan produk lainnya (Firmansyah, 2009). Dalam fermentasi peda, mikroorganisme BAL berperan dalampembentukan cita rasa serta sebagai antimikroba karena dapat menghambat pertumbuhan bakteri pembusuk (Firmansyah, 2009; Lawalata, 2012).

\section{BAHAN DAN METODE Tahap Fermentasi}

Sebanyak $10 \mathrm{~g}$ terasi Empang ditimbang dan dilarutkan ke dalam larutan garam tanpa Iodium dengan konsentrasi $20 \% \quad(\mathrm{~g} / \mathrm{L})$. Larutan ini selanjutnya dijadikan sebagai sumber BAL. Sebanyak 4 ekor ikan kembung (Rastrelliger sp.) dengan berat $400-450$ gram direndam dalam larutan garam sumber BAL selama 3 jam.Setelah perendaman, ikan diangkat dan dikeringanginkan, diberikan perlakuan penggaraman $15 \%, 20 \%$ dan $25 \%(\mathrm{~b} / \mathrm{b})$ difermentasi selama 7 hari (Fermentasi I). Pada hari ke-8 ikan dibongkar dari wadah fermentasi dan kemudian dicuci dengan air bersih dan dikeringanginkan selama 12 jam. Selanjutnya diberi garam dengan konsenterasi $15 \%, 20 \%$ dan $25 \%$ (b/b) untuk fermentasi II, dengan cara disusun dalam wadah fermentasi yang telah dilapisi sekam padi dan daun pisang kering. Fermentasi II dilakukan selama 21 hari, hari ke-22 ikan dibongkar dan dibersihkan dari sisagaram dan terbentuk Peda. Selanjutnya dilakukan uji sensori dilakukan terhadap peda hasil penelitian.

\section{Uji sensori Peda}

Uji sensori dilakukan berdasarkan skala hedonik oleh 5 orang panelis ahli. Kriteria yang dinilai meliputi penampakan warna, aroma, tekstur dan rasa Peda. Bahan disajikan secara acak dengan kode-kode tertentu dan dinilai oleh panelis. Kriteria penilaian menggunakan angka skala 
hedonik (Timoryana, 2007) dengan ketentuan sangat suka (4), suka (3), kurang suka (2), dan tidak suka (1). Data yang diperoleh dianalisis dengan uji Kruskal Wallis.Apabila hasil analisis berbeda nyata, maka dilanjutkan dengan uji Multiple Comparation pada $\alpha 5 \%$.

\section{HASIL PENELITIAN DAN PEMBAHASAN}

Penelitian fermentasi ikan kembung (Rastrelliger sp.) menjadi peda dilakukan dengan memberi perlakuan kadar garam yang berbeda yakni $15 \%, 20 \%$, dan $25 \%$ per berat badan ikan, dan penambahan starter Bakteri Asam Laktat (BAL) yang bersumber dari terasi produk lokal tradisional (terasi Empang). Penambahan starter BAL pada pembuatan peda ini bertujuan untuk menambah mikroba fermentor sehingga mutu peda yang dihasilkan akan menjadi baik. Hasil penelitian penambahan starter BAL dalam bentuk isolat murni pada fermentasi peda dapat memberikan pengaruh yang nyata yakni meningkatkan mutu peda, baik dari segi gizi, warna, aroma, tekstur dan citarasanya (Adawyah, 2006; Irianto, 2012). Hal ini disebabkan karena BAL mampu menghasilkan asam organik berupa asam laktat dan senyawa asetaldehida dalam proses metabolismenya. Asam laktat dan senyawa asetaldehida yang dihasilkan oleh aktivitas metabolisme BAL ini dapat berperan sebagai pembentuk citarasa serta sebagai antimikroba untuk menghambat bakteri pembusuk (Firmansyah, 2009). Dari hasil ini berarti bahwa penambahan starter BAL dalam proses fermentasi dapat meningkatkan mutu produk hasil fermentasi. Peranan BAL dalam pembentukan citarasa peda yaitu melalui penguraian lemak dan protein kompleks menjadi senyawa-senyawa yang sederhana (Adawyah, 2006; Irianto, 2012). BAL juga mampu menghambat pertumbuhan bakteri pembusuk dan bakteri patogen. Penghambatan ini disebabkan karena bakteri asam laktat mampu menghasilkan senyawa anti bakteri yaitu asam laktat, hidrogen peroksida, diasetil dan bakteriosin (Wardani, dkk., 1999).

Penelitian untuk uji hedonik peda dengan penambahan BAL menunjukkan hasil yang berbeda-beda pada parameter warna, aroma, tekstur, dan rasa. Uji hedonik dilakukan dengan melakukan skoring dan tanggapan panelis. Hasil uji hedonik adalah sebagai berikut:

\section{Parameter Warna}

Penilaian mutu bahan makanan pada umumnya sangat bergantung pada beberapa faktor, antara laincita rasa, warna, aroma, tektur, dan nilai gizinya. Parameter warna merupakan pertimbangan pertamakonsumen untuk memilih suatu produk bahan pangan sebelum mempertimbangkan parameter yang lain.Penampakan warna peda pada penelitian ini memperilihatkan peda dengan warna pucat hingga merah kecoklatan.Hasil uji hedonik panelis terhadap parameter warna yang paling baik terdapat pada perlakuan penggaraman $25 \%$ dengan kategori suka

(Tabel1). 
Tabel 1. Data hasil uji hedonik Peda terhadap parameter warna

\begin{tabular}{ccccccc}
\hline \multirow{2}{*}{ Ulangan } & \multicolumn{7}{c}{ Konsenterasi Garam } \\
\cline { 2 - 7 } & \multicolumn{2}{c}{$\mathbf{1 5 \%}$} & \multicolumn{2}{c}{$\mathbf{2 0 \%}$} & \multicolumn{2}{c}{$\mathbf{2 5 \%}$} \\
\cline { 2 - 7 } 1 & 2,8 & 4,5 & 2,8 & 4,5 & 3,2 & $\mathbf{X}$ \\
2 & 2,8 & 4,5 & 2,8 & 4,5 & 2,8 & 4,5 \\
3 & 2,6 & 1 & 2,8 & 4,5 & 3,4 & 9 \\
\hline Jumlah $(\Sigma)$ & 8,2 & $\mathbf{1 0}$ & 8,4 & $\mathbf{1 3 , 5}$ & $9, \mathbf{4}$ & $\mathbf{2 1 , 5}$ \\
\hline rata-rata & 2,73 & & 2,80 & & 3,13 & \\
\hline
\end{tabular}

Keterangan : X menunjukkan skor yang diberikan panelis, $\mathrm{R}$ menunjukkanrangking skor. Namun demikian, hasil uji Kruskal-Wallis untuk melihat kesukaan panelis terhadap parameter warna menunjukkan bahwa warna peda dari perlakuan penambahan garam 15 , 20 , dan $25 \%(\mathrm{~b} / \mathrm{b})$ tidak menunjukkan perbedaan tingkat kesukaan panelis dengan hasil hitungnya yaitu Xhitung $(4,361)<$ Xtabel $(5,99) \quad($ Tabel 2)

Tabel 2. Uji Kruskal-Wallis terhadap parameter warna peda.

\begin{tabular}{ccccc}
\hline $\begin{array}{c}\text { Sember } \\
\text { keragaman }\end{array}$ & Nilai & Df & $\mathbf{X}^{2}$ hitung & $\begin{array}{c}\mathbf{X}^{2} \text { tabel } \\
\mathbf{5 \%}\end{array}$ \\
\hline $\mathrm{RXj}^{2} / \mathrm{n}$ & 248,2 & 2 & 4,361 & 5,99 \\
$\Sigma(\mathrm{RXij})^{2}$ & 267,5 & & & \\
$\mathrm{~N}(\mathrm{~N}+1)^{2 / 4}$ & 225 & & & \\
$\mathrm{~S}^{2}$ & 5,313 & & & \\
\hline
\end{tabular}

Peda dengan perlakuan penggaraman 20 dan $25 \%$ memiliki warna merah kecoklatan, sementarapeda dengan konsenterasi penggaraman $15 \%$ terlihat berwarna lebih pucat. Pada umumnya peda yangbaik dan disukai konsumen mempunyai daging berwarna merah cerah (Adawyah, 2006; Irianto, 2012).Karakteristik warna peda sangat ditentukan oleh bahan baku dan aktivitas enzim dari bakteri. MenurutKetaren (1986), proses hidrolisis dan oksidasi lemak pada tubuh ikan akan menghasilkan perubahanwarna (discoloration). Adawyah (2006) menambahkan, terbentuknya warna merah pada Peda disebabkanaktivitas enzim dari bakteri pembentuk warna merah/orange selama fermentasi, aktivitas bakteri ini jugamenyebabkan terjadi interaksi antara karbonil yang berasal dari oksidasi lemak dengan gugus asam aminodan protein. Pigmen yang terdapat pada bakteri dapat diklasifikasikan ke dalam jenis pigmen karotenoid,antosianin, tripilmethen, dan phanazin.

\section{Parameter Aroma}

Aroma peda pada penelitian ini tercium aroma khas fermentasi peda dan beraroma agak tengik.Hasil uji hedonik panelis terhadap parameter aroma peda yang paling baik terdapat pada perlakuanpenggaraman $25 \%$ dengan kategori kurang suka (Tabel 3). 
Tabel 3 Data hasil uji hedonik Peda terhadap parameter Aroma

\begin{tabular}{ccccccc}
\hline \multirow{2}{*}{ Ulangan } & \multicolumn{6}{c}{ Konsenterasi Garam } \\
\cline { 2 - 7 } & $\mathbf{1 5 1}$ & $\mathbf{R X 1}$ & $\mathbf{X 2}$ & $\mathbf{R X 2}$ & $\mathbf{X 3}$ & $\mathbf{2 5 \%}$ \\
\cline { 2 - 7 } 1 & 2,6 & 6,5 & 2,4 & 2 & 2,6 & 6,5 \\
2 & 2,4 & 2 & 2,4 & 2 & 2,6 & 6,5 \\
3 & 2,6 & 6,5 & 2,6 & 6,5 & 2,6 & 6,5 \\
\hline Jumlah $(\Sigma)$ & 7,6 & $\mathbf{1 5}$ & 7,4 & $\mathbf{1 0 , 5}$ & 7,8 & $\mathbf{1 9 , 5}$ \\
\hline rata2 & 2,53 & & 2,47 & & 2,60 & \\
\hline
\end{tabular}

Keterangan : X menunjukkan skor yang diberikan panelis, $\mathrm{R}$ menunjuk kan rangking skor. Namun demikian, hasil uji Kruskal-Wallis tidak menunjukkan perbedaan tingkat untuk melihat kesukaan panelis terhadap kesukaan panelis dengan hasil hitungnya parameter aroma Peda dari perlakuan yaitu Xhitung $(2,667)<$ Xtabel $(5,99)$ penambahan garam 15, 20, dan $25 \%$ (b/b) (Tabel 4).

Tabel 4 Uji Kruskal-Wallis terhadap parameter aroma Peda

\begin{tabular}{ccccc}
\hline $\begin{array}{c}\text { Sember } \\
\text { keragaman }\end{array}$ & Nilai & Df & $\begin{array}{c}\mathrm{X} 2 \\
\text { hitung }\end{array}$ & $\begin{array}{c}\mathrm{X} 2 \text { tabel 5 } \\
\%\end{array}$ \\
\hline$\Sigma \mathrm{RXj}^{2} / \mathrm{n}$ & 238,5 & 2 & 2,667 & 5,99 \\
$\Sigma(\mathrm{RXij})^{2}$ & 265,5 & & & \\
$\mathrm{~N}(\mathrm{~N}+1)^{2 / 4}$ & 225 & & & \\
$\mathrm{~S}^{2}$ & 5,063 & & & \\
\hline
\end{tabular}

Aromakhas peda disebabkan karena adanya senyawa metal keton dan butil aldehid hasil hidrolisis lemak(Adawyah, 2006), sedangkan aroma tengik terbentuk akibat rusaknya jaringan lemak pada tubuh ikanakibat proses oksidasi serta proses hidrolisis lemak oleh enzim lipase pada tubuh ikan menjadi asamlemak dan gliserol (Gaman dan Sherrington, 1992; Irianto, 2012). Aroma tengik juga karena adanya asamlemak dan senyawa-senyawa pembentuk citarasa seperti senyawa aldehid, keton, dan metal keton akibatoksidasi lemak dan penguraian protein (Ketaren, 1986 dan Adawyah 2006). Irianto (2012) menyatakan bahwa pada produk fermentasi peda yang dibuat dari ikan yang disiangi isiperutnya menghasilkan aroma yang lebih tengik. Hal ini disebabkan karena pembuangan isi perut akanmemberikan permukaan yang lebih luas untuk proses oksidasi yang dapat menimbulkan bau tengik.Sedikit aroma dan rasa tengik kadang-kadang masih dapat diterima, namun jika terlalu keras akanmenggangu rasa (Irianto, 2012), mungkin adanya aroma tengik inilah yang mengindikasikan kurangsukanya panelis terhadap produk hasil fermentasi peda.

\section{Parameter Tekstur}

Selain warna dan aroma, tektur peda juga sangat berpengaruh terhadap kesukaan konsumen.Tekstur merupakan karakter sifat fisik yang ditimbulkan oleh elemen struktural bahan pangan yang dapatdirasakan olah perabaan (Purnomo, 1995). Tekstur peda pada penelitian yaitu pada kategori kurang masirhingga masir. Penilaian uji hedonik panelis terhadap parameter tekstur peda yang paling baik 
terdapatpada perlakuan penggaraman $20 \%$ dengan kategori suka (Tabel 5).

Tabel 5 Data hasil uji hedonik Peda terhadap parameter Tekstur

\begin{tabular}{ccccccc}
\hline \multirow{3}{*}{ Ulangan } & \multicolumn{6}{c}{ Konsenterasi Garam } \\
\cline { 2 - 7 } & \multicolumn{2}{c}{$\mathbf{1 5 \%}$} & \multicolumn{2}{c}{$\mathbf{2 0 \%}$} & \multicolumn{2}{c}{$\mathbf{2 5 \%}$} \\
\cline { 2 - 7 } 1 & $\mathbf{X 1}$ & $\mathbf{R X 1}$ & $\mathbf{X 2}$ & $\mathbf{R X 2}$ & $\mathbf{X 3}$ & $\mathbf{R X 3}$ \\
2 & 3,2 & 8 & 3,2 & 8 & 3 & 4,5 \\
3 & 3 & 4,5 & 3,2 & 8 & 2,8 & 1,5 \\
\hline Jumlah $(\Sigma)$ & 9,2 & $\mathbf{1 7}$ & 9,2 & $\mathbf{1 7 , 5}$ & 8,8 & $\mathbf{1 0 , 5}$ \\
\hline rata2 & 3,07 & & 3,07 & \multicolumn{3}{c}{2,93} \\
\hline
\end{tabular}

Keterangan : X menunjukkan skor yang diberikan panelis, $\mathrm{R}$ menunjukkan rangking dari skor.

Hasil uji Kruskal-Wallis untuk melihat dan $25 \%$ (b/b) tidakmenunjukkan kesukaan panelis terhadap parameter perbedaan tingkat kesukaan panelis dengan tekstur menunjukkan bahwa tekstur peda hasil hitungnya yaitu $\mathrm{X}$ hitung $(2,667)<\mathrm{X}$ dari perlakuan penambahan garam 15, 20, tabel $(5,99)$ (Tabel 6).

Tabel 6 Uji Kruskal-Wallis terhadap parameter tekstur peda

\begin{tabular}{ccccc}
\hline $\begin{array}{c}\text { Sumber } \\
\text { Keragaman }\end{array}$ & Nilai & Df & $\begin{array}{c}\mathbf{X}^{2} \\
\text { hitung }\end{array}$ & $\begin{array}{c}\mathbf{X}^{2} \text { tabel 5 } \\
\%\end{array}$ \\
\hline$\Sigma \mathrm{RXj}^{2} / \mathrm{n}$ & 235,2 & 2 & 1,549 & 5,99 \\
$\Sigma(\mathrm{RXij})^{2}$ & 277,5 & & & \\
$\mathrm{~N}(\mathrm{~N}+1)^{2 / 4}$ & 225 & & & \\
$\mathrm{~S}^{2}$ & 6,563 & & & \\
\hline
\end{tabular}

Peda yang baik memiliki tekstur daging yang masir. Konsistensi masir pada peda sangatdipengaruhi oleh kandungan lemak yang tinggi dan adanya enzim proteolitik yang akan mengubah teksturikan sehingga menjadi masir (Adawyah, 2006). Tekstur masir pada peda dipengaruhi oleh kadar air danaktivitas air bahan serta kandungan protein dan lemak bahan (Purnomo, 1995).

\section{Parameter Rasa}

Rasa merupakan salah satu faktor penentu mutu bahan makanan. Flavor atau rasa sebagairangsangan yang ditimbulkan oleh bahan yang dimakan, yang dirasakan oleh indra pengecap ataupembau, serta rangsangan lainnya seperti perabaan dan penerimaan derajat panas oleh mulut (De Man,1997). Rasa peda pada penelitian ini adalah rasa khas fermentasi peda. Hasil uji hedonik panelis terhadapparameter rasa Peda yang paling baik yaitu pada perlakuan penggaraman $25 \%$ dengan kategori suka(Tabel 7). 
Tabel 7. Data hasil uji hedonik Peda terhadap parameter rasa

\begin{tabular}{|c|c|c|c|c|c|c|}
\hline \multirow{3}{*}{ Ulangan } & \multicolumn{6}{|c|}{ Konsenterasi Garam. } \\
\hline & \multicolumn{2}{|c|}{$15 \%$} & \multicolumn{2}{|c|}{$20 \%$} & \multicolumn{2}{|c|}{$25 \%$} \\
\hline & $\mathbf{X 1}$ & RX1 & $\mathbf{X 3}$ & $\mathbf{R X 3}$ & $\mathbf{X 5}$ & RX5 \\
\hline 1 & 2,8 & 4,5 & 3 & 7 & 3 & 7 \\
\hline 2 & 2,4 & 1 & 2,6 & 2,5 & 3,2 & 9 \\
\hline 3 & 2,6 & 2,5 & 3 & 7 & 2,8 & 4,5 \\
\hline Jumlah $(\Sigma)$ & 7,8 & 8 & 8,6 & 16,5 & 9 & 20,5 \\
\hline Rata-rata & 2,60 & & 2,87 & & 3,00 & \\
\hline
\end{tabular}

Keterangan : X menunjukkan skor yang diberikan panelis, $\mathrm{R}$ menunjukkan rangking dari skor.

Namun demikian, hasil uji Kruskal-Wallis untuk melihat kesukaan panelis terhadap parameter rasa menunjukkan bahwa rasa Peda dari perlakuan penambahan garam 15, 20, dan $25 \%(\mathrm{~b} / \mathrm{b})$ tidak menunjukkan perbedaan tingkat kesukaan panelis dengan hasil hitung yaitu X hitung $(3,813)<$ Xtabel $(5,99)$ yang berarti tidak berbeda nyata (Tabel 8).

Tabel 8 Uji Kruskal-Wallis terhadap parameter rasa peda

\begin{tabular}{ccccc}
\hline $\begin{array}{c}\text { Sumber } \\
\text { Keragaman }\end{array}$ & Nilai & Df & $\begin{array}{c}\mathbf{X}^{2} \\
\text { hitung }\end{array}$ & $\begin{array}{c}\mathbf{X}^{2} \text { tabel 5 } \\
\%\end{array}$ \\
\hline$\Sigma \mathrm{RXj}^{2} / \mathrm{n}$ & 252,2 & 2 & 3,813 & 5,99 \\
$\Sigma\left(\mathrm{RXij}^{2}\right.$ & 282 & & & \\
$\mathrm{~N}(\mathrm{~N}+1)^{2 / 4}$ & 225 & & & \\
$\mathrm{~S}^{2}$ & 7,125 & & \\
\hline
\end{tabular}

Rasa yang khas pada peda terbentuk akibat adanya penguraian protein dan lemak pada tubuhikan. Senyawa komplek lemak diuraikan menjadi asam lemak dan gliserol, senyawa proteinkompleks diuraikan menjadi asam-asam amino dan senyawa cita rasa seperti senyawa metal keton danbutil aldehid (Adawyah, 2006). Penguraian senyawa-senyawa kompleks pada peda terjadi akibataktivitas enzim yang dihasilkan bakteri fermentor seperti Acinetobacter, Flavobacterium, Halobacteriumatau Halococcus, Corynobacterium, dan Lactobacillus (Adawyah, 2006; Irianto, 2012). Bakteri terisolasi dari prodak Peda adalah Staphilococcus sp. (Savitri, 2006); bakteri genus Laktobacillus, Sterptococus, dan Pediococus (Rahayu, dkk.,

1999);Lactobacillus cirvatus, L. sake, L. murinus, L. Plantarum, dan Streptococus termophilus (Santoso, dkk., 1999).

Mikrobayang berperan dalam proses fermentasi termasuk mikroba yang tidak bersifat patogen, tapi umumnyadapat merusak lemak dengan menghasilkan cita rasa tengik, disamping menghasilkan perubahan warna(discoloration) (Ketaren, 1986). Santoso, dkk. (1999), menemukan bakteri yang berperan pada fermentasiterasi dan Peda memiliki aktivitas penghambat terhadap bakteri patogen dan pembusuk.

Dalam penelitian ini, perlakuan konsenterasi penggaraman dan penambahan starter BAL berupalarutan terasi tidak menunjukkan perbedaan yang nyata antar perlakuan untuk setiap parameter baik darisegi warna, aroma, 
tekstur, maupun rasanya. Namun jika dilihat dari rata-rata penilaian panelis terhadapparameter penilaian, panelis lebih cenderung menyukai peda dengan perlakuan penggaraman yang palingtinggi yaitu $25 \%$ dengan kategori suka. Dari hasil penilain ini, terdapat kesamaan tingkat kesukaanpanelis antara peda dengan konsenterasi penggaraman $25 \%$ dengan penambahan BAL dan Peda dengankonsenterasi penggaraman $30 \%$ tanpa penambahan BAL pada penelitian yang dilakukan oleh Desniar,dkk., (2009), yakni berada pada kategori suka.

Hasil uji hedonik peda dalam penelitian ini hanya pada tingkat suka, hal ini kemungkinandisebabkan karena BAL yang ditambahkan dalam fermentasi Peda ini kurang maksimal dalammembentuk senyawa citarasa. Dalam penelitian ini starter yang digunakan adalah berupa larutan terasi.Kurang maksimalnya kinerja starter BAL ini kemungkinan disebabkan sumber BAL yangdigunakan sebagai starter tidak berupa kultur mikroba yang diisolasi dari produk fermentasi ataupunkultur murni bakteri asam laktat. Kamil, dkk., (1975) dalam Irianto(2012), menggunakan starter berupa formulasi daging ikan peda dan tepung kacang hijau. SelanjutnyaIrawadi (1979) dalam Irianto (2012), menggunakan starter Lactobacillus sp. yang diisolasi dari asinankubis. Penambahan starter tersebut dapat meningkatatkan mutu Peda.Kemungkinan lain yang mengindikasikan kurang maksimalnya kerja starter BAL dalampenelitian ini adalah bakteri dalam terasi yang ditambahkan kurang mencukupi serta waktu perendamanikan dalam sumber BAL (larutan terasi) terlalu singkat (3 jam). Perendaman ikan dalam sumber BALyang singkat ini kemungkinan menyebabkan mikroba-mikroba yang ada dalam larutan terasi belum bisa melakukan reproduksi secara maksimal, sehingga mengakibatkan jumlah sel mikroba (starter BAL) yangtumbuh tidak terlalu banyak. Kurang banyakknya jumlah mikroba starter pada tubuh ikan menyebabkanmikroba-mikroba tersebut kurang maksimal dalam proses fermentasi peda.

Penggunaan bakteri asam laktat (BAL) dari larutan terasi sebagai starter dalam pembuatan pedadiharapkan dapat membantu industri peda skala rumah tangga. Penggunaan starter BAL berupa kulturmurni atau isolate BAL dari produk fermentasi lainnya hanya bisa dilakukan di laboratorium, sehinggaakan meningkatkan biaya produksi. Selain itu, pemanfaatan terasi sebagai starter BAL dalam penelitiandikarenakan adanya kesamaan bakteri asam laktat yang berperan dalam fermentasi peda dan terasi sepertiyang dijelaskan oleh Santoso, dkk. (1999) diatas, sehingga dimungkinkan penggunaan terasi sebagaistarter mikroba dalam fermentasi peda.

\section{SIMPULAN}

Pembuatan Peda melalui fermentasi ikan kembung (Rastralliger sp.)dengan penambahan Bakteri Asam Laktat (BAL) yang terkandung dalam terasi Empang menghasilkan Peda dengan sifat hedonic yang paling dapat diterima panelis, dilakukan pada perlaukuan pemberian konsentrasi garam $25 \%$ dan lama waktu fermentasi 21 hari.

\section{DAFTAR PUSTAKA}

Adawyah, R.. 2006. Pengolahhan dan pengawetan Ikan. Jakarta : Bumi Akssara.

De Man, J.M.. 1997. Kimia Makanan. Bandung: Penerbit ITB.

Desniar, D. Poernomo, dan W. Wijatur. 2009. Pengaruh Konsentrasi Garam pada Peda Ikan Kembung (Rastrelliger sp.) dengan Fermentasi Spontan. 
Bogor: Institut Pertanian Bogor Press.

Firmansyah, D. 2009. Profil Fenoleptik Isolat Bakteri Asam Laktat yang Berasal dari Daging Sapi. [Skripsi]. Bogor: Fakultas Peternakan Institut Pertanian Bogor.

Gaman, P.M., dan K. B. Sherrington. 1992. Ilmu Pangan, pengantar Ilmu Pangan Nutrisi dan Mikrobiologi, Edisi Kedua. Diterjemahkan oleh Gardjito, M., S. Naruki, A. Murdiati, danSardjono. Yogyakarta : Gadjah Mada University Press.

Irianto, H.E.. 2012. Produk Fermentasi Ikan. Jakarta : Penebar Swadaya.

Ketaren, S.. 1986. Pengantar Teknologi Minyak dan Lemak Pangan. Jakarta: UI-Press.

Khasanah, N.. 2009. Pengaruh Konsentrasi Garam Terhadap Protein Hasil fermentasi Ikan Kembung (Rastrelliger sp.) pada Pembuatan Peda sebagai Alternatif Sumber Belajar Kimia SMA/MA pada Materi Pokok Makromolekul [Skripsi]. Yogyakarta : Universitas Islam Negeri Sunan Kalijaga.

Lawalata, H.J.. 2012. Keanekaragaman Bakteri Asam Laktat Penghasil Antimikroba Selama Proses Fermentasi Bekasang. [Disertasi]. Yogyakarta: Fakultas Biologi Universitas Gadjah Mada.

Purnomo, H.. 1995. Aktivitas Air dan Peranannya dalam Pengawetan
Makanan. Jakarta: UI-Press.

Rahayu, E.S., S. Okada, T. Uchimura, dan K. Komagata. 1999. Lactic Acid Bacteria in Fermented Foods of Indonesian Origin. [Abstrak]. Asian Network on Microbial Research Symposium on MicrobialDiversity The Asian Science, Singapore, $22-24$ February 1999.

Santoso, E., E.S. Rahayu, dan T. Utami. 1999. Bakteri Asam Laktat pada Terasi dan Peda serta Aktivitas Penghambatannya terhadap Bakteri Patogen dan Bakteri Pembusuk. [Abstrak]. ProsidingSeminar Nasional Pangan -Yogyakarta, 14 September 1999.

Savitri, S.D.N. 2006. Isolasi dan Karakterisasi Bakteri Halotoleran pada Peda Ikan Kembung (Rastralliger sp.). [Skripsi]. Bogor: Program Studi Teknologi Hasil Perikanan Fakultas Perikanan dan Kelautan Institut Pertanian Bogor.

Timoryana, V.D.F.. 2007. Studi Pembuatan Kecap Ikan Selar (Caranx leptolepis) dengan Fermentasi Spontan. [Skripsi]. Bogor : Fakultas Perikanan dan Ilmu Kelautan Institut Pertanian Bogor.

Wardani, A.K., S. Margino, E.S. Rahayu, B. Ray. 1999. Purifikasi dan Karakterisasi Bakteriosin dari Louconostoc Lactis BR-8. [Abstrak]. Prosiding Seminar Nasional Pangan Yogyakarta, 14September 1999 